\title{
The Drought-Migration Nexus: Implications for Socio-Ecological Conflicts in Nigeria
}

\author{
${ }^{*}$ C.K Ajaero \\ A.T Mozie \\ I.C. Okeke \\ J.P. Okpanachi \\ C.Onyishi \\ Department of Geography, University of Nigeria Nsukka, and \\ Demography and Population Studies Programme, \\ University of Witwatersrand, Johannesburg, South Africa \\ Chukwuedozie.ajaero@unn.edu.ng; chukwuedozie.ajaero@wits.co.za
}

\section{Doi:10.5901/mjss.2015.v6n2s1p470}

\section{Abstract}

In Nigeria, the droughts in 1972 - 1975 and floods since 1988 marked the incidence of climate change. This study evaluates the linkages between drought-desertification causative climatic variables over time, the consequent migration caused by the climatic variations and socio-ecological conflicts in Nigeria. Climate data was obtained from the Nigeria Meteorological Agency and analyzed with the correlation and regression models. The data on conflicts was obtained from the National Emergency Management Agency and the public media The results of correlation analysis are; between cumulative number of conflicts and temperature (0.974), moisture balance (-0.838), time (0.735), and annual total rainfall(-0.918). The regression results also indicated from the direction and sizes of the coefficients that the reversal and rejuvenation of the damaged ecosystem if left to occur naturally will take a very long time. The ethical dimension of socio-ecological conflicts was appraised. Finally, suggestions for mitigating socio-ecological conflicts such as the need for advocacy and attitude re-orientation of the largely uneducated, poor and ignorant rural dwellers were made.

Keywords: Conflicts; Desertification; Drought; Migration; Nigeria; Socio-ecological.

\section{Introduction}

The Inter-Governmental Panel on Climate Change (2007) identified the effects of climate change to include drought and desertification, floods, violent winds, spread of diseases, threat to food sources etc. Suffice it to say that the effects of climate change are now being felt in most parts of Nigeria (Okpanachi, 2010; Igweoku, 2009; Onyishi, 2013 ).

Furthermore, it has been shown that the northern fringes (Sudano-Sahelian region) of Nigeria have had episodes of drought, and a continuous history of progressive desiccation (Mortinore, 1973; James 1973; Bernus, 1973; Grove, 1973; Kowal and Adeoye, 1973; Kowal and Kassan, 1973). The experience in the Sudano-Sahelian region of Nigeria is that of a steady "advance" of the Sahara desert causing swathes of erstwhile viable grazing and arable and to become unavailable and unproductive (www.unep.org, 2007). For Instance, Okeke's (2010) study of climate change over Gusau showed a trend of increasing temperature and reducing water balance. In addition, Oguejiofor (2013) showed that the desiccation front has been advancing southwards prompting the government of the Federation of Nigeria and the governments of the states which are affected to develop programmes for checking the advancement of the desiccation front.

Mozie (2009) predicted that the sea level rises along the coastal areas of Nigeria and the desiccation that will occur in the northern region of Nigeria will set off waves of spatial adjustment of population via migration from the two extreme areas towards the central section of Nigeria. In the context of this paper therefore, the effects of desertification in the Sudano-Sahelian region of Nigeria has forced stronger and larger waves of the migration of herdsmen, their families and herds southwards into the wetter parts of Nigeria where there are vegetation to feed their cattle. These migrating herdsmen are Fulani and Plate 1 shows a typical migration of the Fulani with their herd of cattle. 


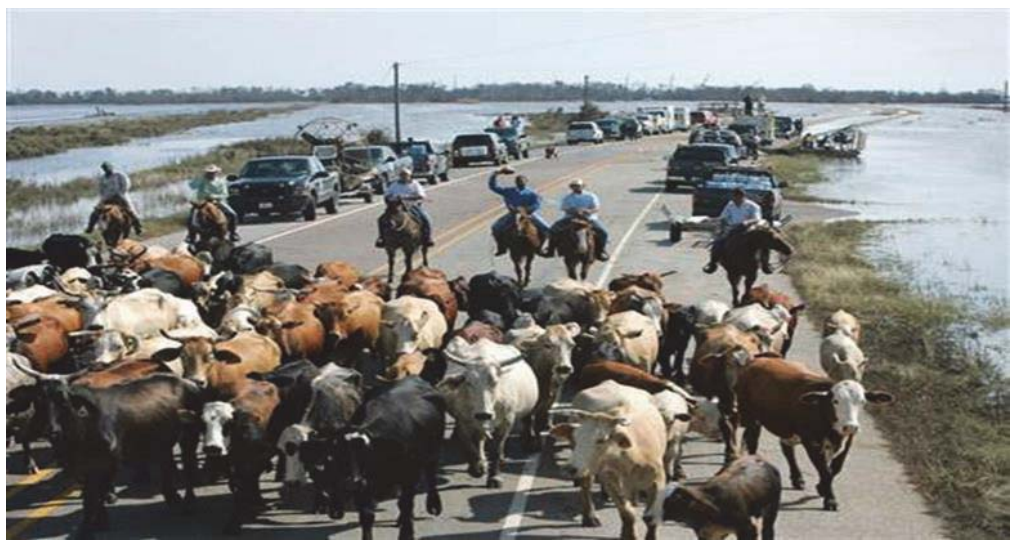

Plate 1: Fulani herdsmen migrating southwards with their cattle

The migrating Fulani have their pastoral culture as opposed to the "town" or "settled" Fulani who have become sedentary. The pastoral or cattle Fulani does not recognize the conventional boundaries between groups. Their wealth and way of life is in their herds of cattle which they must feed and protect. Since the "we" and "they" syndrome remains a reality in Nigeria, and the populations in developing countries attach tremendous importance to land as both an inheritance and property, conflicts between the migrating Fulani and the indigenous populations of the areas they migrate to becomes inevitable. Mass murder of inhabitants of communities and conflicts between migrating Fulani and settled indigenous groups has occurred over the last few years in various parts of Nigeria. Recently, the public print media has posted news that suggest that the pastoralists seek and take grazing land vi et armis acting in terrorem. Although forest reserves and wildlife sanctuaries exist in Nigeria, there are no really officially designated grazing reserves in Nigeria. There is a supposition that if these reserves exist, they would offer protection to the herds of cattle whose food reserves are being depleted by the desiccation. Therefore, the objectives of this study are to evaluate the linkages between droughtdesertification causative climatic variables over time, to highlight the consequent migration caused by the climatic variations and to examine the linkages between climate change-induced migration and socio-ecological conflicts in Nigeria. In order to achieve these objectives, This paper will examine the relationship between desertification variables of temperature increase, reduction in rainfall, reduction in water balance, and depletion of vegetation on one hand, and increase in the number of conflicts between the Fulani herdsmen and farming communities on the other hand.

\section{Method of Study}

\subsection{Theoretical Framework:}

(a) The Eco-violence Theory: This paper utilizes the theory of eco-violence which was developed by Homer-Dixon (1999). This theory aims at explicating the relationship between environmental/climatic factors and violent conflicts. According to this theoretical construct, the decrease in the quality and quantity of renewable resources, population growth, and resource access act singly or in various combinations to increase the scarcity, for certain population groups, of vegetation, farmland, water, forests etc. This scarcity of ecological resources can reduce economic productivity, both for the local groups experiencing the scarcity and for the larger regional and national economies. Consequently, the affected people may migrate or be expelled to new lands. Migrating groups often trigger ethnic conflicts when they move to new areas, while decreases in wealth can cause deprivation conflicts (Homer-Dixon, 1999:30). Implicit in the eco-violence theory is the assumption that competition over scarce ecological resources engenders violent conflict. This trend has been aggravated in contemporary times owing to the impacts of climate change, which has exacerbated ecological scarcity across the world (Blench, 2004; Onuoha, 2007). In this study, the theory of eco-violence will offer insights into the issue of desertification, migration, and herdsmen-host community conflicts in Nigeria. It should be noted that the conflicts have been driven by the desperation of the affected groups to protect and advance their livelihood interests in the context of an ever shrinking ecological space, characterized by resource-scarcity, 
livelihood crisis, population explosion, and resource competition. These conflicts have also been accentuated by the climate change-induced migration of pastoralists from the far North of Nigeria in search of grazing fields (Blench 2004). The outcome of this scenario in Nigeria has been the prevailing internecine herder-farmer conflict, which has so far defied all remedies.

\subsection{Data Collection and Analysis}

This study utilized both quantitative and qualitative methodologies because of the nature of variables studied. Consequently, temperature and rainfall data from 1970 to 2012 for three stations in the Sudano-Sahelian region of Nigeria which lie roughly on latitude $12^{\circ} \mathrm{N}$ were obtained from the Nigerian Meteorological Services (NIMET) Oshodi, Lagos. The annual means of the temperature and rainfall were plotted against the year in which they were recorded to obtain their fluctuations. The rainfall and temperature were used to compute the water balance for the study area using the Book keeping method. The fluctuations in the temperature, rainfall and water balance were smoothed using a fiveyear moving average to discern the trend in the data sets. The incidences of attacks by the pasture seeking nomads was collected from published sources such as newspaper reports, government publications, key informants and other news media from 1985 to the present period. The incidences of these conflicts were summed cumulatively for the period. The number of conflicts was thereafter associated with temperature, rainfall and moisture balance using the Pearson correlation and the simple linear regression models. Finally, the phenomenon of desert encroachment is discussed with regards to migration and conflicts.

\section{Results and Discussion}

\subsection{Temperature}

The trend of the temperature in the Savanna region of Nigeria is shown to have remained on the increase as reflected in Figure 1. The period from 1990 marks the period of appreciable increase in temperature in the area. The correlation coefficient between temperature and time is determined to be +0.6 while the regression model is $Y=23.95+0.029 x$.

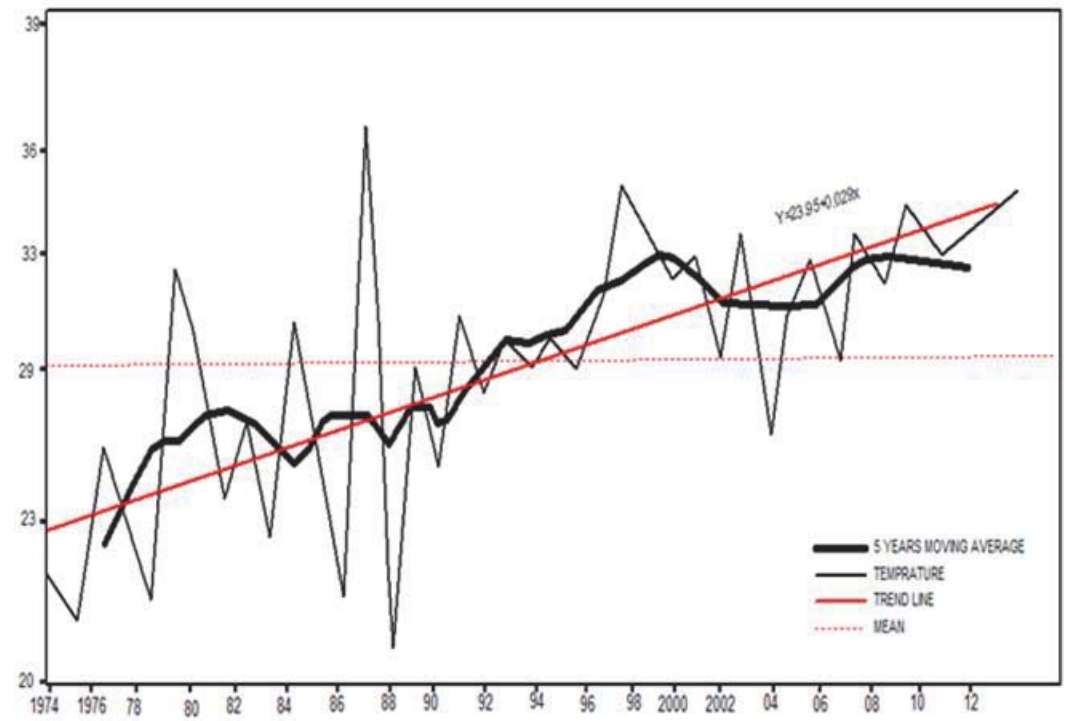

Figure 1. Annual variations in temperature in the savanna region of Nigeria (1974-2012)

\subsection{Rainfall}

Kowal and Adeoye (1973) stated that rainy season in Nigeria increases in length southwards at the rate of 20 rainy days 
per degree of latitude and that there is a general decrease of rainfall with increasing latitude in Nigeria. Also, Eze (2014) recently derived a trend equation of regional rainfall in Nigeria stated thus:

$$
Z=2850.21+22.74 x-204.20 y \ldots
$$

The equation indicates that for each increase in longitude there is a proportionate increase of $22.74 \mathrm{~mm}$ of rainfall and for each increase in latitude there is a $204.20 \mathrm{~mm}$ proportionate decrease in amount of rainfall. However, Kowal and Adeoye (1973) derived a regression equation of $Y=94.48-5.10 x$ for northern Nigeria indicating that mean annual rainfall decreases on average of $127.50 \mathrm{~mm}$ for every increase in the degree of latitude. They reached a conclusion that at latitude $18^{\circ} .30^{\prime}$ North, no rains may be expected, and these results present quantitative data explaining the progressively lesser rainfall as one moves northwards. Without rainfall or moisture of any sort as there are no exotic streams in this part of the Sahel, pasture is very scarce or scanty. The results of analysis of the fluctuations in the annual rainfall totals from 1970 to 2012 are shown in Figure 2. The trend shows a decrease in the rainfall in the savanna. Further analysis in the data also show decrease in the length of rainy days represented in the regression equation $(Y=124.1-0.064 x)$, increase in the duration of the dry season $(Y=240.7+0.073 x)$, decrease in the duration of the rains in the rainy season $(Y=$ $894.1-0.62 x)$, increase delay in the date of the onset of the rainy season $(Y=142.0-0.64 x)$, and the shortening early stoppage of the onset of dry season $(Y=255.7+0.25 x)($ Okeke, 2010).

The short rainfall situation is further aggravated by the faster retreat of the overhead sun and the $\mathrm{mT}$ and the ingress of the dry and dusty tropical continental air mass (cT) in September-October. As soon as the rains retreat, the moisture deficit reflects on the withering of vegetation which persists until the rains return. The fact remains that the grasses fail to reach their former state of abundance due to over-grazing and bush burning. For the period of the drying of the vegetation, the soils are exposed to the direct incidence of the sun and the evaporative effects of the winds leading to soil desiccation and corresponding damages to crops and pasture. The attenuation of the adverse effects of desiccation is the major reason for the establishment of shelter belts in the states at the extreme northern boundaries of Nigeria (Oladapo, 1993; Punch, 1988; Federal Ministry of Environment, 2002; Abdulsalam, 2009).

\subsection{Loss of Vegetation}

The uni-directional trend and the regression equations derived for the region give unequivocal evidence of sustained desiccation in the region from the northern to the southern parts. The works of Mortinore (1973), James (1973); Fry (1973), Grove (1973), Kowal and Adeoye (1973), Kowal and Kassam (1973), Appledorn (1981), Oladapo (1993), Adepetu and Berthe (2007) and Adediran (2010) provide sufficient information on drought, and desertification in the SahelSavanna in Nigeria and their effects. Drought and desertification constitute a special class of challenges that command global attention Hewitt (1997) and (IPCC, 2007). The ultimate effects of drought and desertification are that the soils and vegetation are dried out; the vegetation dies off; the soils are exposed to the direct evaporative effects of the sun and the winds and the winds erode, deposit and re-arrange the topography by establishing sand dunes. The consequence for the populations affected is for them to fight the drought and desertification, die or migrate (Mortimore, 1973, 1989).

\subsection{Desertification-migration-conflict nexus}

The net effect of the ecosystem damage was the emergence of desert cum semi-desert characteristics by the degraded surface as the moisture balance tilted to the negative. The emerging regime of high temperatures and reduced moisture which is global accelerated the ecosystem damage and the spread of the desert scape. Onyewotu (1983) that noted that from 1981 when the effects of the desertification had set off the initial migrations, the Federal Government set out to combat the menace by commencing the programme of shelter-belt construction using drought resistant tree species especially the Eucalyptun camaldulensis to stop the advance of the desert. The tree stands were inter-cropped with the millet (Pennisetum typhoides) a drought-resistant grain as a model for the local people to follow (Onyewotu and Stigter, 1995). 


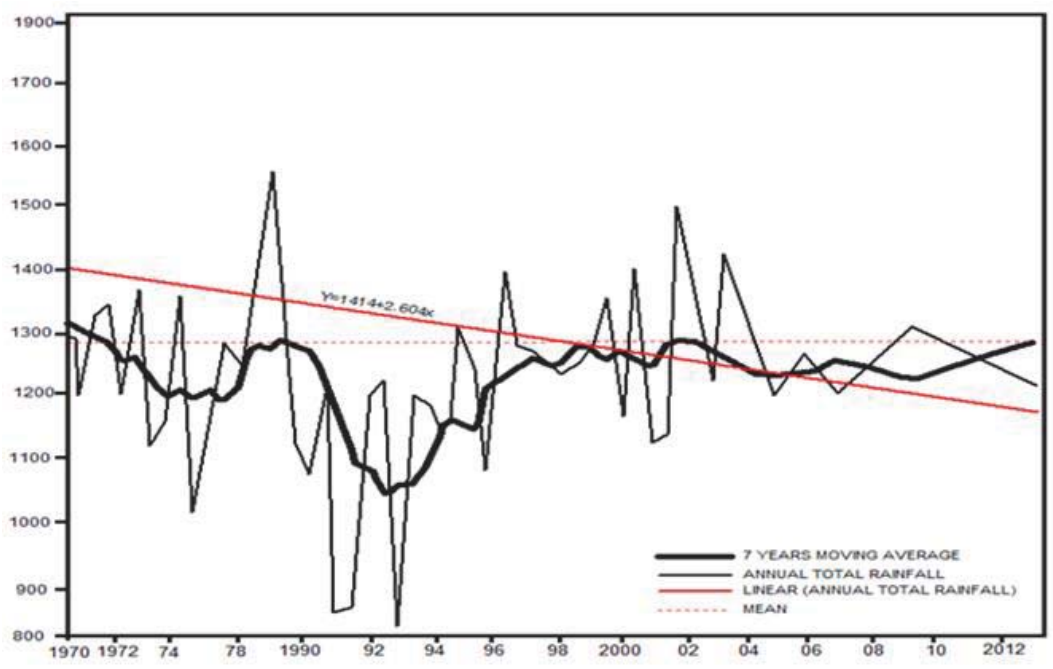

Figure 2: Trend results of the annual rainfall totals from 1970 to 2012

The droughts of 1983 - 1985 effectively started the southward shift of the local population as the carrying capacity of the land which stood at about 40 persons per square kilometer with herds of cattle added, could barely sustain 20 persons per square kilometer. As the land available for livelihood was shrinking; the population was increasing at a rate of $3 \%$ per year (Oluyemi-Kusa, 2014). At the same time, the cattle rearers have been recording more litters of cattle causing them to need more land to graze their increasing cattle. The response of the Fulani cattle owners and their herdsmen is to migrate into areas of better foliage occupied by communities of sedentary farming populations and the struggle for land has been a constant feature of life in the lands where the cattle of the Fulani destroy and eat up crop stands cultivated by the farmer communities. Table 1 shows the data of the study variables from 1984-2013.

Table 1: The trend of the study variables from 1984-2013

\begin{tabular}{|ccccc|}
\hline $\begin{array}{c}\text { Cummulative number of } \\
\text { years }\end{array}$ & $\begin{array}{c}\text { Cummulative number of } \\
\text { conflicts }\end{array}$ & $\begin{array}{c}\text { Temperature } \\
\text { Trend }(\mathrm{OC})\end{array}$ & $\begin{array}{c}\text { Rainfall } \\
\text { trend(mm) }\end{array}$ & $\begin{array}{c}\text { Moisture balance } \\
\text { trend }\end{array}$ \\
\hline 0 & 6 & 24.5 & 1275 & 1870 \\
\hline 3 & 7 & 26.3 & 1270 & 1865 \\
\hline 5 & 8 & 26 & 1220 & 1820 \\
\hline 9 & 13 & 29 & 1200 & 1800 \\
\hline 16 & 25 & 31 & 1180 & 1810 \\
\hline 17 & 30 & 32 & 1175 & 1820 \\
\hline 18 & 33 & 33 & 1170 & 1822 \\
\hline 19 & 40 & 34 & 1168 & 1780 \\
\hline 25 & 42 & 33.5 & 1165 & 1730 \\
\hline 26 & 45 & 34 & 1164 & 1725 \\
\hline 27 & 90 & 34.5 & 1160 & 1780 \\
\hline 28 & 170 & 35 & 1160 & 1784 \\
\hline 29 & 205 & 36 & 1157 & 1755 \\
\hline
\end{tabular}

Consequently, the degree of the association between the temperature, the total annual rainfall, moisture balance on the one land, and the number of conflicts between the sedentary farming communities and the Fulani herdsmen yielded the following results contained in Table 2. 
Table 2: Table of correlation coefficients between the study variables

\begin{tabular}{|c|c|}
\hline No of conflict vs Time & 0.735 \\
\hline No of conflict vs Temperature & 0.974 \\
\hline No of Time vs Rainfall & -0.918 \\
\hline No of Time vs Moisture & -0.838 \\
\hline
\end{tabular}

Source: Author's computations (2014)

It can be seen from Table 2 that the coefficients of correlation for the pairs of variables are

(a) The number of conflicts and time: There is a strong positive correlation indicating the increase in the number and frequency of conflicts for land and pasture between the Fulani herdsmen and the farming communities. Oluyemi-Kusa (2014), Okeke (2014) and other scholars have observed that the modern day Fulani herdsmen are armed with sophisticated battle field weapons such as the CETIME and AK-47 assault rifles. In some cases, their dexterity, timing and expertise of their invasions of host communities have caused some scholars to risk expressing the views that the Fulani cattle owners are hiring professional fighters from some neighboring countries which have just emerged from internecine conflicts such as Chad and Niger republic (Oluyemi-Kusa, 2014). The multiplicity and tenacity of the attacks clearly indicate the clear intent of the Fulani to take and secure grazing lands for their cattle which is the common measure and index of wealth in their mittieu. The unfolding scenario is scary- and portends insecurity for all of Nigeria (Fasona and Omojola, 2005).

(b) The number of conflicts and temperature: The results indicate that there is a strong positive correlation between the number of conflicts and the trend of temperature $(r=0.974)$; a strong negative correlation between the number of conflicts and the trend of annual total rainfalls $(r=0.784)$ and a strong negative correlation between the number of conflicts and the moisture balance $(r=0.843)$ in the Sahel Savanna of Nigeria.

(c) The number of conflicts versus rainfall and moisture trends: There is also evidence that the rainfall has been decreasing $(r=-0.918)$ and the moisture balance decreasing progressively with time $(r=-0.838)$. From these results, the relationship between the ecological damage is seen to progress through the disruption of the balance in the environment system in the erstwhile Sudan Savanna areas turned to Sahel Savanna and still deteriorating to desert. The over-exploitation of the vegetation altered the evaporative section of the hydrological cycle. Over-exploitation of the vegetation also opened up the soil to accelerated moisture loss. The vegetation loss was still sustained by the uncontrolled exploitation and adverse practice of bush burning which tradition was aptly captured in Ekwensi's "Burning Grass" (Ekwensi, 1961). The already bad situation was aggravated by the change in the climate regime to a warmer and drier state (Archer, 2007; IPCC, 2001). The adverse situation elicited responses from the people in the Sahel. The cattle owners in order to protect their wealth ordered their footmen to seek better grazing land and empowered them with modern weapons with which to meet overcome any groups that resist their ingress and settlement in the areas with better pasture. It may then be seen that the population in the Sahel having damaged the ecosystem, the pasture shrank and they seek to take their destructive practices, including damaging cultivated food crops by the other farming communities to other parts of Nigeria.(http://www.irinews.org/reportaspx? report.id=8476) Accessed Aug., 2013.

In addition, the regression analyses show that the cumulative number of conflicts, the dependent variable $(Y)$ was regressed against the cumulative number of years $\left(X_{1}\right)$, temperature $\left(X_{2}\right)$, rainfall $\left(X_{3}\right)$ and moisture balance $\left(X_{4}\right)$. The regression equations from the analysis are stated thus:

(d) Between time and temperature $(Y=-19.065+0.714 \mathrm{x})$, and the ANOVA test is significant at $p=0.001$. The significance of the relationship is reflected in the size of the intercept (base constant) which is below zero indicating a steep slope of the regression line and a very strong association reflected in the size of the correlation coefficient 0.735 .

(e) The multiple regression between cumulative number of conflicts the dependent variable $(Y)$ regressed against the predictor variables number of years $\left(X_{1}\right)$, temperature $\left(X_{2}\right)$, rainfall $\left(X_{3}\right)$ and moisture balance $\left(X_{4}\right)$ is stated thus

$Y=-2393.258+1.703 X_{1}-0.012 X_{2}+0.672 X_{3}+0.405 X_{4}$

The equation is significant at $p=0.001$ indicating a strong association between the dependent and predictor variables. The scale of the relationship indicates a negative intercept and a steep-slope regression line indicating a strong 
association between the dependent and independent variables. The base constant of the equation is the amount in the dependent variable that must occur or exist for the magnitude of changes in the predictor variables in the direction indicated by the + or - signs attached to them (Anyadike, 2009). With respect to the equation, the relationship between the number of conflicts and the cumulative number of years (life span) indicates that it will take 1.703 years above the present span of time that the conflicts have occurred 29 years before a reduction in the number of conflicts can be achieved (-2393.258). This relationship indicates a more turbulent future for the people of Nigeria for as long as the environmental deterioration continues in the Sahel-Sudan vegetation and climate zones.

The relationship between temperature trend and number of conflicts indicates that a reduction in the rate of increase of the temperature in the Sahel of 0.012 will lead to a reduction in the scale of -2393.258 in the number of conflicts. The size of the temperature reduction indicates that it will take a very long time for an equable temperature to be achieved by natural processes of ecosystem rejuvenation and status reversals. The relationship suggests that there should be a very deliberate intervention to acceleration the repair of the damaged ecosystem by the people and governments of the Sahelian states of Nigeria. In addition, an increase in the rainfall of the scale of 0.672 will yield a reduction of -2393.258 in the scale of conflicts. This means that the ecosystem in the Sahel must revert to its original state for the vegetation cover, the southward migration of the herdsmen, and the associated conflicts to be reversed.

\subsection{The ethical dimensions of socio-ecological conflicts}

Most of the ecological problems we witness today are caused by humans. For instance, man is in his quest for "development" has remained largely responsible for the problem of ozone depletion that has continued to bug the environment till date. Scientists have observed that the ozone layer holes are caused by chlorine-bearing pollutants such as the chlorofluorocarbons used in fire extinguishers and as refrigerants, cleaning agents, and spray propellants (Barbara, 2004). Development and environment are two concepts that should be seen as closely related and capable of moving forward together. To this end, talks about sustainable environment should be seen as talks about development that does not ignore environmental concerns. Speth (1981:1-4) noted that "it is...clear that development and economic reforms will not have lasting effect unless they are suffused with concern for ecological stability and wise management of resources. As has already been pointed out, the ecological crises as we witness today in Nigeria and indeed in most part of the world, are in some cases natural and in some others man-made. Consequently, human-induced environmental degradation is the fall-out of humans' effort at survival and social development. There can hardly be any form of social development if nature or the environment is left untouched. Houses, markets, industries, parks, schools, churches and so on must be put in place. These feats cannot be achieved if humans do not encroach upon nature. Besides, the principle that "to sustain life, another life may need to be destroyed," finds reality in man-nature relationship. As a result of the observed worsening environmental and socio-ecological situations, humans began to question and rethink their relationship with the natural environment and their fellow human beings. This new disposition resulted in the emergence of pro-environmental literatures, movements as well as conventions. All these were necessitated by the realization of the need to protect the natural environment, and subsequently reduce socio-ecological conflicts. Among the environmentalists and philosophers that wrote in defense of the environment were the likes of Rachel Carson (Silent Spring, 1962), Paul Ehrlich (The Population Bomb, 1974), Mark Sagoff (Economy of the Earth, 1988), and Peter Singer (Animal Liberation, 1973), (Yang, 2006). In 1972, the United Nations organized its first conference on environment aimed at awakening environmental consciousness worldwide in Stockholm. This was followed by international laws pertaining to environmental protection. These clarion calls for a fundamental change of values vis-à-vis the environment and the subsequent response to these calls by public-spirited individuals paved the way for the emergence of the modern-day environmental ethics.

Being holistic in outlook, deep ecology is a perspective that is grounded in a vision of non-exploitive science and technology (Barbara, 2004). That over-population of humans on earth now poses a serious threat to human existence through persistent socio-ecological conflicts is a vindication of the ecocentric claim that both humans and non-human contents of the environment are equal moral citizens of the biotic community with interdependency such that the disharmony in one class or arm of the biotic community means a distortion in the ontological web of existence of the whole biotic community. It has to be observed, however, that there is every need for a balanced and harmonious relationship between individuals, communities and all of nature. This, indeed, is the message of deep ecology under the auspices of ecocentrism (Diara, Ajaero and Asogwa 2014). 


\section{Conclusion}

This study set out to establish an empirically plausible relationship between desertification, migration and the multiple conflicts between the Fulani herdsmen and the settled agrarian communities in Nigeria. This was carried out by examining the relationship between the number of conflicts over time and in relation to the climatic variable of annual temperatures, rainfalls and moisture balance for the period of study in the Sudan-Sahel region of Nigeria. The climatechange based "desert encroachment" theory of ecological change was questioned and rejected. The man-based ecological change theory was suggested in place of the rejected theory. The correlation coefficients indicated strong to very strong relationships between the pair of correlated variables which were all significant indicating that the observed relationships were not chance or cursory in nation. The multiple linear regression equation also indicated from the direction and sizes of the coefficients that the reversal and rejuvenation of the damaged ecosystem if left to occur naturally will take a very long time. This is a direct indication of the inertia and 'fixed' nature of natural ecosystems. The results suggest that the exploitation of natural resources must be guided to avoid ecosystem damage. The results also suggest the need for advocacy and attitude re-orientation of the largely uneducated, poor and ignorant rural dwellers who see the ecosystem as their bank of economic resources which they must exploit to raise money to meet their needs (Itjake, 2008). The situation as it is revealed calls for very deliberate and honest intervention by the Federal Government of Nigeria if it hopes to avert the looming wars that must by inevitably be fought by the contending groups who are locked in a war of survival - the Fulani having their food and wealth in their crops with other politico-ethno-religious and economic factors stoking the energies of the parties and foreign interests. The Nigerian government on her part should come up with more environmental friendly policies that will take into consideration the greater welfare of the people, especially those in the area where natural and human-induced environmental degradation and disaster have reduced or tend to reduce their humanity. Finally, the authors hazard the view that if unchecked appropriately, the pastoralistsfarmers war holds a different and more potent danger to the corporate survival of Nigeria than any other event.

\section{References}

Aaron, S. (2011) Climate Change Adaptation and Conflict in Nigeria. Special report of the United States Institute for Peace, Washington D.C. Abdulsalam, A.F. (2009) Sokoto Local Government Councils establish Shelterbelts. Nigeria General Topics. http://www.Nigerian bestforum.com (Accessed 6 October 2009).

Adediran, I.D. (2010) The Socio-Economic Implication of Climate Change, Desert Encroachment and Communal Conflicts in Northern Nigeria: Climate Change, Conflict and Livelihoods, Conference Paper, Climate Change and Security, 250th Anniversary, The Royal Norwegian Society of Sciences and Letters, Trondheim, Norway, 21 - 24 June, 2010.

Adepetu, A.A and Bertne, A. (2007) Vulnerability of Rural Sahelian Households to Drought: Options for Adaptation. A Final Report Submitted to Assessments of Impacts and Adaptation to Climate Change (AIACC) Project No. AF 92.

Ajaero, C.K and Mozie, A.T. (2011) "The Agulu-Nanka Gully Erosion Menace in Nigeria: What Does the Future Hold for Population at Risk", In Leighton, M., Smen, X. and Warner, K. (2011) Climate Change and Migration: Rethinking Policies for Adoption and Disaster Risk Reduction, Source, No. 15, United Nations University, Institute of Environmental and Human Security, Munich, Germany.

Anyadike, R.N.C. (2009) Statistical Methods for the Social and Environmental Sciences. Ibadan, Spectrum Books Ltd.

Apeldorn, G.J. (1981): Perspectives on Drought and Famine in Nigeria. London, George Allend Nnwin.

Bernus, E. (1973) Drought in Niger Republic. Savanna, vol. 2, No 2, December 1973, pp. 129 - 132.

Bovill EW (1958) The Gold Trade of the Moors London Oxford University Press.

Diara, B.C., Ajaero, C. K. and Asogwa, N.U (2014) The linkages between ecological insecurity and lack of peace in the Nigerian society. Pensee Journal, Vol. 76 (9), 228- 245.

Ekwensi, C.O.D. (1961) Burning Grass. African Writers Series. Heinemann, Ibadan.

Ezeh, C.U. (2014) Sequences of Daily Rainfall Variations Across Nigeria. Unpublished M.Sc. Thesis), Department of Geography, University of Nigeria, Nsukka.

Ezirim, G.E and Onuoha, F.C. (2008) Climate Change and National Security: Exploring the Theoretical and Empirical Connections in Nigeria. International Journal of International Politics and Development, vol. 4, Nos, 1 and 2.

Fashona, M.J. and Omojola, A.S (2005) Climate change, human security and communal clashes in Nigeria. Paper presented at the International Workshop in Human Security and Climate Change, Oslo, Sweden. June 2005.

Federal Ministry of Environment (2002) Desertification and desert encroachment in Nigeria. Environmental Annual Project, Abuja, vol. $14,2002$.

Fry, C.N. (1973) Avian indicators of increasing environmental aridity at Zaria. Savanna. Vol. 2, No 2, December 1973, pp. 126 - 128.

Grove, A.T. (1973) A note on the remarkably low rainfall of the Sudan zone in 1913. Savanna, vol. 2, No. 2, December 1973, pp. 133 - 138.

Hanger, I (2014) The Fulani-Tiv at War in Nigeria as President Jonathan Helplessly Looks on (1), Accessed from: The Fulani-Tiv at war in Nigeria as Presid on 10th July, 2014. 
Hewitt, K. (1997) Regions at Risk. A Geographical Introduction to Disasters, Addison-Wesley, Longmans.http://www.irinnews.org/report. aspx?reportid=84761 (accessed 10 July 2014).

Igweoku, M.A (2009) Variations in Climatic Water Balance over Jos, (Unpublished B.Sc. Project) Department of Geography, University of Nigeria, Nsukka.

IPCC (2001) Climate Change 2001: Synthesis Report. A contribution of Working Groups I, II and III to the Third Assessment Report of the IPCC.

IPCC (2007) Fourth Annual Report: "Synthesis Report Summary for Policy Makers". Retrieved from www.wikipedia.org, May 10, 2009.

James, A.R. (1973) Drought Conditions on the Pressure Water Zone of North-Eastern Nigeria: Some Provisional Observations. Savanna, vol.2, No 2, pp $108-114$.

Jones, B. (1938) Desiccation and the West African Colonies. Geogr. Journal, No. 91, pp. 401 - 422.

Kowal, J.M and Adeoye, J.B. (1973) An assessment of aridity and the severity of the 1972 drought in Northern Nigeria and neighbouring countries. Savanna, vol. 2, No. 2, pp. $145-158$.

Kowal, J.M and Kassam, A,H (1973) An Appraisal of Drought in the Guinea and Sudan Savanna areas of Nigeria. Savanna, vol. 2, No. 2, pp. $159-164$.

Mortimore, M.J. (1973) France in Hausland. Savanna, Vol.2, No.2, pp. $103-105$.

Mortimore, M.J (1989) Adapting to Drought: Farmers, Famine and Desertification in West Africa, Cambridge University Press, Cambridge.

Mozie, A.T. (2009) "A Case for the Adoption of the Worst-Scenario Doctrine in Responding to Sea Level Changes in Nigeria's Coastal Regions". In Anyadike, R.N.C., Madu, I.A. and Ajaero, C.K. Eds (2009) Climate Change and the Nigerian Environment. Jamoe Press, Enugu.

Mozie, A.T. (2011) Human Factors in Flood Hazards and Disasters in Nigerian Cities. Paper presented at the Collogium on Climate Change, 1st - 3rd Dec. 2011, Fac. of Soc, Sci., University of Nigeria, Nsukka.

Mozie, A.T; Ayadiuno, R.U; Onyekwelu, C.A and Upa, C (2014) "Assessing Earthquake Risks along the West African Coast in the present Climate Change Setting", (Under review).

Nicholson, S (2005) "Climatic Variations in the Sahel and Other African Regions during the Past Five Centuries", Journal of Arid Environments, 1, 3-24.

Oguejiofor, H.A (2013) Assessment of the Efficacy of Shelterbelts in the Sahel Region of Nigeria. Unpublished M.Sc Project, Department of Geography, University of Nigeria, Nsukka.

Ojo, $O$ et. al. (2001) Fundamentals of Physical and Dynamic Climatology. Lagos, SEDEC Press Ltd.

Okeke, C.I. (2010) Rainfall Variability over Gusau Zamfara State, Nigeria. Unpublished B.Sc Project, Department of Geography, University of Nigeria, Nsukka.

Okeke, O.E. (2014) Conflicts between Fulani Herders and Farmers In Central and Southern Nigeria; Discourse on Proposal establishment of Grazing Routes and Reserves. International Journal of Arts and Humanities, vol. 3, No.1, Jan., 2014, pp. 66 84

Okpanachi, J. (2010) Rainfall Variability over Minna. Unpublished B.Sc. Project, Department of Geography, University of Nigeria, Nsukka.

Oladipo, E.O. (1993) A Comprehensive Approach to Drought and Desertification in Northern Nigeria. Natural Hazards, pp. 235 - 261.

Oluyemi,-Kusa, D (2014) "Pastoralists and Farmers Conflicts in Nigeria", Accessed from: dayokusa.blogspot.com /2014/03/ pastoralists farmers, conflicts-in-nigeria.html (accessed on10 July, 2014).

Onah, S.I and Chilaka, F.C. (2012) Climate Change and Conflict in Nigeria: A Theoretical and Empirical Examination of the Worsening Incidences of Conflict between Fulani Herdsmen and Farmers in Nigeria", Arabrain Journal or Business Management Review, vol. 2, No. 1,

Onyewotu, L.O.Z (1983) Structural Design and Orientation of Shelterbelts in Northern Nigeria: Suggested establishment considerations. Agricultural Meteorological Journal, vol. 29, pp. $27-38$.

Onyewotu, L.O.Z and Stigter, C.J. (1995) Eucalyptics - its reputation and its roots: Millet and a Eucalyptus Shelterbelt in Northern Nigeria. Agroforestry Today, vol. 7, No. 1, pp. 7 - 8.

Onyishi, C.A. (2013) Influence of Climate Change on Human Comfort over Onitsha, Anambra State. Unpublished B.Sc. Project, Department of Geography, University of Nigeria, Nsukka.

Punch (1988) Climate Change in Northern Nigeria. Punch Newspapers, Lagos, Punch Publishing Co., Ltd. July 12 - 14.

Stebbing, E.P (1935) The Encroaching Sahara. Geogr. Journal, No. 85, pp. 506 - 524.

THE ECONOMIST (1995) "Reading the Patterns" April 1995, London, pp. 83 - 85. www.economist.org.

Udo, R.K. (1971) Geographical Regions of Nigeria, Ibadan, Heinemann.

United Nations Environment Programme (2007) Desertification File www.unep.org Accessed 6th July, 2007.

\section{Figure Legend}

Plate 1: Fulani herdsmen migrating southwards with their cattle

Figure 1: Annual variations in temperature in the savanna region of Nigeria (1974-2012)

Figure 2: Trend results of the annual rainfall totals from 1970 to 2012 